\title{
Apolipoprotein B-100
}

National Cancer Institute

\section{Source}

National Cancer Institute. Apolipoprotein B-100. NCI Thesaurus. Code C106032.

Apolipoprotein B-100 (4563 aa, $\sim 516 \mathrm{kDa}$ ) is encoded by the human APOB gene. This protein plays a role in both transport and cellular uptake of LDL particles. 